\title{
Social Inquiry: Journal of Social Science Research
}

2020, Vol. 2, No. 2, pp. 158-193

https://doi.org/10.3126/sijssr.v2i2.33059

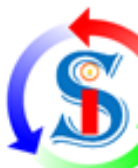

Open Access

Article History: Received: 22 February 2020 | Revised: 14 September | Accepted: 24 September 2020

Original Article

Spatial Variation of Caste/Ethnic Poverty in Mountain Districts of Nepal: An Approximation through Small Area Estimation Technique

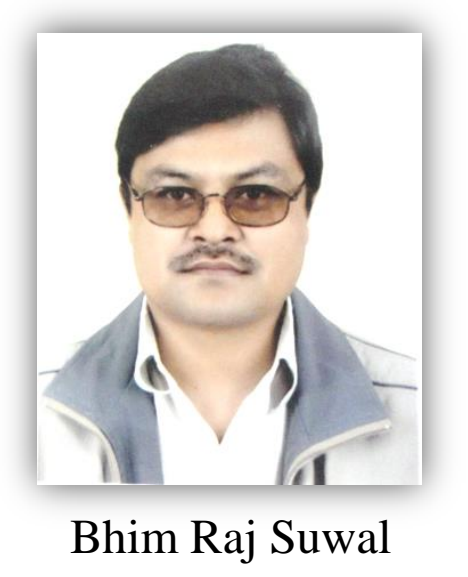

Spatial Variation of Caste/Ethnic Poverty in Mountain Districts of Nepal: An Approximation through Small Area Estimation Technique

Email: bhim.suwal@ fohss.tu.edu.np

(D) https://orcid.org/ 0000-0003-4097-1154

(c) (i) (C) 2020 The Author(s). This open access article is distributed under the terms of the Creative Commons Attribution-NonCommercial-ShareAlike (CC-BY-NC-SA) International Public License (https://creativecommons.org/licenses/by-nc-sa/4.0/), which permits noncommercial re-use, distribution, and reproduction in any medium or format, provided the original work is properly cited and such creations are licensed under the identical terms. 


\section{Abstract}

Nepal is a multi-ethnic and multi-cultural society where economic condition of various caste/ethnic groups substantially varies. However, adequate attention has not been paid to estimate the level of monetary poverty of various caste/ethnicities and assess how people of the same caste/ethnicity living in different locations (districts) vary in terms of monetary poverty. Focusing only on mountain belt, which is one of the economically poorest areas of the country, this study aims to estimate incidence of monetary poverty for major caste/ethnicities living in the mountain districts with the help of small area estimation (SAE) technique and assess spatial variation in the incidence of monetary poverty of the same caste/ethnic group living along the east-west continuum of the mountain districts. Required data for SAE is derived from Nepal Living Standard Survey (2010/11) and 2011 population census of Nepal. The study shows that, compared to other districts, three eastern mountain districts (Province 1) (Taplejung, Sankhuwasabha, and Solukhumbu) have lowest incidence of poverty for all the caste/ethnicities with much lower incidence in three socioeconomically advanced hill caste groups. Incidence of poverty tends to increase sharply along the east to west continuum of mountain districts with exceptionally high poverty rates for Dalits in the far western mountain districts (Province 7). Some culturally similar caste/ethnic groups follow almost similar pattern of increase in the incidence of poverty along the east-west continuum of the mountain districts and form districts of clusters in each region with similar level of poverty.

Keywords: Caste/Ethnic Poverty; Small Area Estimation; Mountain

Poverty; Poverty in Nepal; Spatial Variation in Poverty

\section{Introduction}

Based on the topographic and climatic conditions, Nepal is divided into three ecological belts - mountain, hills and
Tarai (plain). There are 77 districts in Nepal, of which, 16 districts are in the mountain belt (Map 1). Mountain belt consists of 35 percent $(51,817$ sq. $\mathrm{km}$.) of the total area of Nepal $(147,181$ sq. 
$\mathrm{km}$.) in which 6.7 percent (or $1,781,792)$ of the country's population reside. Ecological belts of Nepal are primarily a horizontal divide of the country's land based on the climatic conditions of the districts. The landscape of the mountain belt is composed of rugged terrain with cold mountain climate where pastoral economy still widely prevails.

Mountain belt of Nepal is a multiethnic, multi-cultural society. Population census of Nepal 2011 identified 125 caste/ethnic groups in Nepal, of them, 122 are found in the mountain belt (except caste/ethnic groups classified as "Others") (Central Bureau of Statistics [CBS], 2014). The same source shows that 95 percent of the total population residing in the mountain belt is from 20 caste/ethnic groups. They are: Chhetree, Tamang, Brahman - Hill, Kami, Thakuri, Newar, Limbu, Sherpa, Rai, Damai/Dholi, Sarki, Gurung, Magar, Sanyasi/ Dashnami, Thami, Dalit Others, Kulung, Gharti/Bhujel, Lohar, and Yakkha. Chhetree with 36 percent of the total mountain population appears to be the largest caste group in the mountain belt. This is followed by Tamang (12\%), Brahman (10\%), Kami (7\%) and Thakuri (5\%). These five caste/ethnic groups accounted for nearly 70 percent of the total mountain population. Although Chhetree caste in mountain belt, like the country as a whole, deserves first position in terms of population size, its relative share in mountain belt $(36 \%)$ is more than 2 times higher than that of national population $(17 \%)$. 


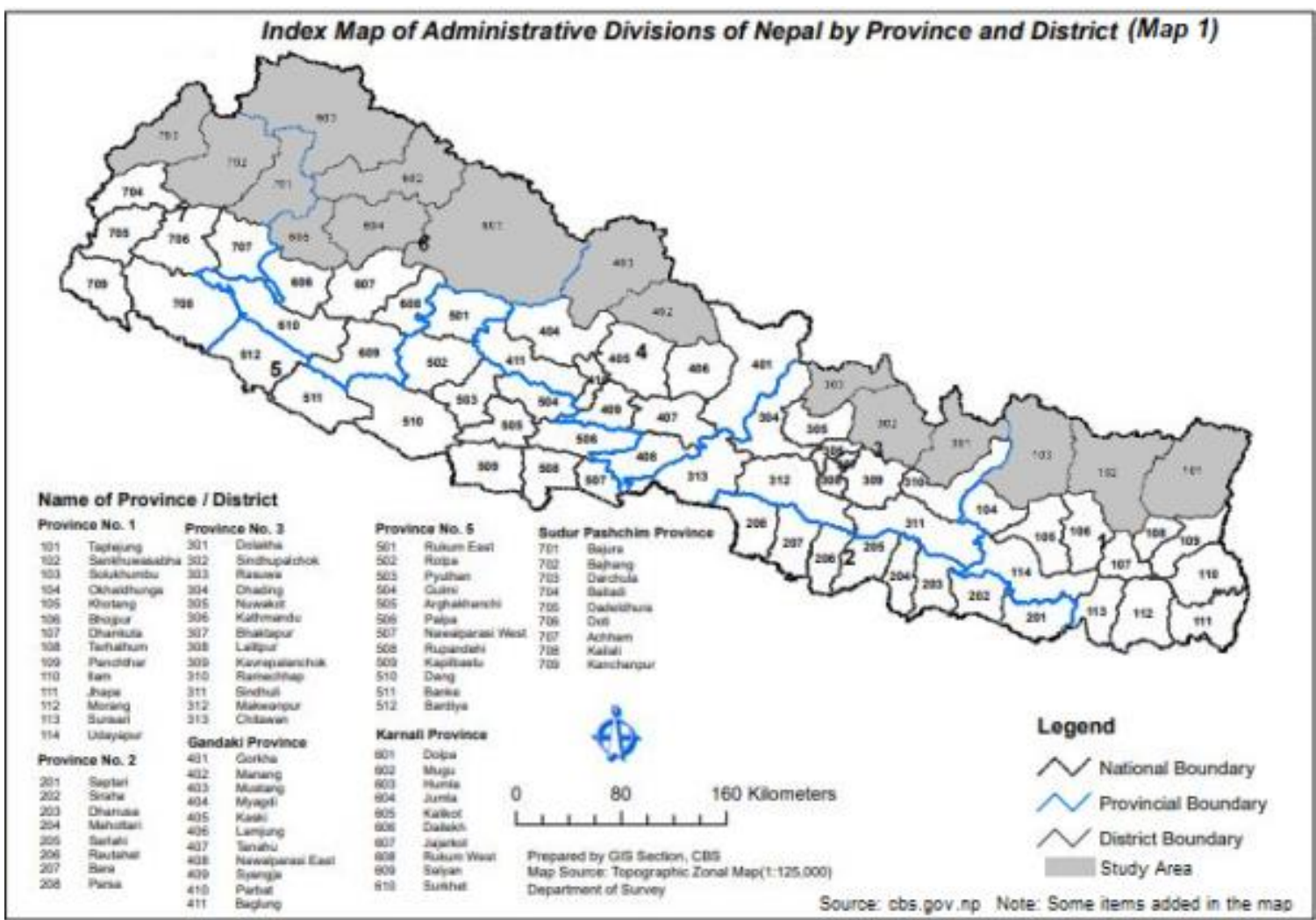

A classification of caste/ethnic groups by districts shows that highest number of 99 caste/ethnic groups are in Sankhuwasabha district and lowest number of 36 in Dolpa. Not all the caste/ethnic groups found in mountain districts are distinct groups meaning that many caste/ethnic groups found in one district are also found in other districts. For example, caste groups like Brahmin-Hill, Chhetree, Sanyasi/ Dasnami, Damai/Dholi, Kami, Sarki are found in almost all the districts. On the other hand, many ethnic groups like
Jirel, Majhi, Yakhha, Bhote, Dolpo are found only in few districts. The population census of Nepal 2011 shows that population size of various caste/ethic groups greatly varies across the districts. For example, of the 71 caste/ethnic groups found in Taplejung district, 52 have population size of 260 or less, and 37 have population size even less than 10 . Nineteen caste/ethnic groups with population size above 260 accounted for 99 percent of the total population in the district. The distribution of population by 
caste/ethnic groups in other mountain districts also follow more or less similar pattern.

In terms of population size, there is a predominance of Chhetree population in four of the far western mountain districts - Jumla (60\%), Bajura (58\%), Bajhang (67\%) and Darchula (65\%). These four districts accounted for nearly 60 percent of the total Chhetree population $(56 \%)$ of the mountain belt. Nearly 80 percent of the Tamang population (77\%) belongs to 3 districts - Sindhupalchowk (48\%), Dolakha (15\%) and Rasuwa (14\%). BrahmanHill and Kami population, on the other hand, show more uniform distribution of population across the mountain districts with the highest 17 percent of Brahman in Sindhupalchok and 20 percent of Kami population in Kalikot. Compared to this, 50 percent of the Thakuri population is concentrated in two districts with the highest 39 percent in Kalikot and 11 percent in Humla district.

\section{Caste/Ethnic Poverty in Mountain Districts}

Various rounds of Nepal Living Standard Survey (NLSS) conducted by CBS are the main sources of data for estimating poverty level in Nepal. The first round of the NLSS was conducted in 1995/96, second round in 2002/2003 and third round in 2010/11. Currently, fourth round of the NLSS is underway. Available estimates on poverty indicate that over the years there has been significant decline in the level of poverty in Nepal. It declined from 42 percent in $1995 / 96$ to 31 percent in 2003/2004 (CBS, 2005). The last round of NLSS 2010/11 indicated further decline of incidence of poverty to 25.2 percent (CBS, 2010/11). Considering caste/ethnicities, hill Dalits have the highest rate of poverty (44\%) being lowest for Newars (10\%).

The estimates of the poverty rates from the NLSS 2010/11 represents percent of the population living below poverty line. This round of NLSS defined population below poverty line in terms of those having annual per capita consumption less than Rs. 19,261 (US\$258 as per August 1, 2010 which approximately represents mid-period of the NLSS 2010/11 survey). Since NLSS estimates of poverty is based on annual consumption data, measures of poverty from the NLSS is generally known as incidence of monetary poverty. It does not include multi-dimensional aspects of poverty and deprivation as measured with multi-dimensional poverty index 
(MPI) (United Nations Development Programme [UNDP], 2010; National Planning Commission [NPC], 2018).

The available estimates further indicate that mountain belt continued to be an area with the highest incidence of poverty. In 1995/96, nearly 60 percent of the mountain people $(57 \%)$ were living below poverty line. Compared to this, other belts (hills \& Tarai) had much lower incidence of poverty (around 40\%). Although incidence of mountain poverty reduced to 33 percent in 2003/04, it was still higher than that of Tarai (28\%) which again increased to 42 percent in 2010/11 being much higher than that of hills (24\%) and the Tarai $(23 \%)$. The reasons for increase in the incidence of mountain poverty during 2003/04-2010/11 is not obvious. However, based on the available information, it may be concluded that incidence of mountain poverty in Nepal, like in other belts, is in declining trend but it is still very high compared to the other belts. Furthermore, mountain belt also demonstrates highest depth as well as severity of poverty (CBS, 2010/11). Despite highest incidence of poverty, mountain belt accounted lowest proportion of the population below poverty line in the country (8-12\%). This is mainly because this belt accounted the lowest proportion of the total population (7-8\%).

Human development approach is another way of understanding levels of poverty. Under this approach, three types of measures are generally used to estimate the level of poverty: human development index (HDI), human poverty index (HPI), and multidimensional poverty index (MPI). The available estimates on HDI and HPI indicate that mountain belt is experiencing remarkable improvement in the aspect of human development. For example, HDI for mountain belt was 0.386 in 1996 which increased to 0.436 in 2006 (UNDP, 2009). Particularly, eastern and central mountain demonstrates further improvement in the human development with increase in HDI to 0.475 in 2011. Improvement in human development in the mountain belt is reflected upon the corresponding decline in the incidence of poverty. For example, HPI for mountain belt in 2001 was estimated to be 49.8 which fell to 43.3 in 2006 (UNDP, 2009), and to 38.5 in 2011 (UNDP, 2014). Despite these improvements, it is to note that mountain belt, if compared with the hills and Tarai, is still lagging much 
behind in terms of human development and poverty.

Multi-dimensional poverty index (MPI) is another measure of poverty which incorporates more number of indicators relating to education, health and standard of living. An estimate of MPI by GoN (2018) for the year 2014 shows that incidence of multi-dimensional poverty in Nepal is 28.6 percent. However, this report does not provide estimates for ecological belts and caste/ethnicities. Based on the NDHS 2011 data, Goli et al. (2019) have estimated MPI of 24 percent for mountain belt which is higher than that of hills and Tarai $(0.22$ or $22 \%)$. They have further concluded that, compared to the hills and Tarai, mountain belt lags far behind in health and standard of living index.

The sources reviewed above are the major sources of data on poverty in Nepal which provide only a macro (national, and by province, region, belts and broad caste/ethnic groups) pictures on poverty from different approaches. These sources indicate that there is substantial variation in incidence of poverty by ecological belt. Evidences also suggest that poverty rate consistently increases when we go from eastern to western part of the country (21\% for eastern region and $45.6 \%$ for far western region) (CBS, 2011). Considering such a large variation in the incidence of poverty by regions, it can be easily inferred that incidence of poverty is not the same for various groups of population living in different regions and districts of the country. Despite this, none of the macro level studies provide any indication about how various groups of the population living in different regions and district vary in terms of incidence of poverty. In this context, taking districts of mountain belt as spatial unit and caste/ethnic population within each district as estimation unit for caste/ethnic poverty, the specific objective of this study is to examine inter-district variation of caste/ethnic poverty (termed as spatial variation of caste/ethnic poverty) in mountain belt in which high incidence of poverty is persistent for a long time. By this study, two particular contributions to the study of poverty in Nepal can be underlined. Firstly, this study provides estimates of poverty rates for individual caste/ethnicities living in each district of mountain belt which none of the previous studies have provided. Secondly, this study assumes that poverty of same caste/ethnicity living in different districts tends to vary. 
Therefore, this study provides districtspecific poverty rates for each caste/ethnicity living in mountain belt. This will help compare incidence of poverty of same caste/ethnic group and identify districts in which a particular caste/ethnic group is economically well or worse off. As noted earlier, direct estimation of poverty by district and caste/ethnicities is not possible from the NLSS data sets due to small sample size. For this, small area estimation (SAE) technique that combines national census, and survey data has been applied to estimate caste/ethnic poverty.

\section{Methods and Materials}

This section describes overall process of estimating incidence of poverty with the use of SAE technique. The major issues covered in this section are: caste/ethnicities included in the analysis, estimation units, and SAE techniques.

\section{Caste/Ethnicities Included in the Analysis}

For the present analysis, any caste/ethnic groups with more than 500 population have been considered as major caste/ethnic group and included in the analysis. According to this criterion, a total of 42 caste/ethnic groups qualify to be the major groups. In addition to this, some caste/ethnic groups having less than 500 population have also been included in the analysis in order to facilitate comparison of poverty rates in a broader context. Among these groups, Kami of Manang has the lowest population size of 246 . With addition of these groups, total number of caste/ethnic groups included in the analysis is 44 (Figure 1). All the caste/ethnic groups included in the analysis hereafter is called major caste/ethnic groups.

\section{Estimation Units}

In this study, spatial units have been represented with districts and each caste/ethnic group within district constitutes one estimation unit (domain). This implies that a particular caste/ethnic group which is identified as a major group in multiple numbers of districts has been treated as separate estimation unit in each district. For example, Kami is identified as a major group in 16 districts and this caste constitutes 16 separate estimation domains, one estimation domain per district. By this principle, there will be a total of 195 estimation units for the present study, although, as noted above, 
only 44 distinct caste/ethnic groups qualify to be major groups. This schema of estimation units has been essential for the present study in order to build east-west (west-east) continuum of each caste/ethnic groups based on the location of the spatial units (districts) and facilitate comparison of caste/ethnic poverty of the same group residing in different districts, more specifically along the east-west continuum of the districts.

\section{Small Area Estimation (SAE) Technique}

There are different types of SAE techniques which are broadly divided into two categories: design-based (direct) and model-based (indirect) (Australian Bureau of Statistics [ABS], 2006). Model-based technique is used when a higher level of accuracy is required. Considering this, in this study, model-based technique has been used. In its simplest terms, the model-based SAE technique is a statistical technique, more specifically regression technique, that predicts an "outcome" variable through simulation in which representative smaller set of data for an area (under study) containing outcome variable and its predictors are used for modelling purpose and model coefficients are simulated to a larger set of data of the same area that contains only predictor variables. The larger data (data set) is generally called auxiliary data and use of auxiliary data, according to Ghosh and Rao (1994), provides strength to the smaller data set to find more accurate estimates for the area under study. Tzavidis (2013) has asserted that SAE can work efficiently (precisely) even when domains (small areas) have small or no sample sizes (planned or unplanned). Based on the unit of analysis, the model can be unit or area level model.

Depending on the nature of the outcome variable, various types of model-based SAE technique have been developed (ABS, 2006). According to Chandra et al. (2009), indirect estimators (modelbased estimators-added by authors) for small area quantities under generalized linear mixed model (GLMM) are often known as empirical best predictors (EBPs) mainly because, as noted by Robinson (1991), EBP has minimum mean squared error. GLMM is also considered to be the best tool for analyzing non-normal data that involve random effects (Bolker et al., 2008). In this study, unit level model has been used to predict household probabilities of being poor which are converted into 
individual probabilities by the use of population weight where family size has been used as population weight.

Among the various regression models, logistic regression is considered to be the appropriate model when outcome variable is binomial variable coded " 0 " and " 1 ". It is to note that this study aims to predict proportion of population living below poverty line (poverty rates) using information provided by the NLSS 2010/11 under the "poor" variable (in poverty file). The "poor" variable constitutes an outcome variable which has two categories: "poor" indicating "households living below poverty line" (coded with "1") and "rich" indicating "households not living below poverty line" (coded with "0"). Considering "poor" variable as a binomial outcome variable, logistic regression has been chosen as an appropriate model for estimating poverty rates. Likewise, in consideration of advantage of EBP model, binomial regression model has been used with logit link function under the hierarchical (multilevel) generalized linear mixed model (GLMM). According to Hofmann at al. (2000), the basic assumption of hierarchical GLMM is that the lower level units are exposed to and influenced by characteristics and/or processes of the higher-level units. Such an effect is estimated by incorporating random effect terms for $i^{\text {th }}$ level (s) in the regression model. The methodology is extensively discussed by Hofmann et al. (2000), Jia at al. (2004), Zhang (2016), Chandra et al. (2009), and Woltman at al. (2012).

According to Zhang (2016), the general procedure of binary logistic regression model for SAE is a four step process in which explanatory model is developed for the estimation of model coefficients using survey data at the first step, model coefficients are applied to auxiliary data to predict individual probabilities at the second step, and estimated probabilities are aggregated (as mean) to the estimation units (here, major caste/ethnic groups) at the third step. The mean for each major caste/ethnic group is an estimate of the proportion of the households living below poverty line. Finally, precision of the estimated proportion is assessed in terms of prediction errors.

\section{Sources of Data}

Required information for the present study are obtained from the two sources: NLSS 2010/11 data sets (used 
as survey data), and population census 2011 data sets (used as auxiliary data). Conducted by CBS, NLSS and population census in Nepal constitute an important part of official statistics. NLSS household data file provides outcome ("poor" variable) as well as predictor variables whereas census data file contains only predictor variables. As per the requirement of SAE technique, information from the NLSS data sets have been extracted and used to develop explanatory model and estimate model coefficients at the first step and model coefficients are simulated to the household data file of the 2011 population census to estimate household probabilities of being poor at the second step. Table 1 summarizes coverage of 2011 population census and NLSS 2010/11.

Table 1

Coverage of Population Census 2011 and NLSS 2010/11

\begin{tabular}{lccc}
\hline Particulars & Districts & $\begin{array}{c}\text { Enumeration } \\
\text { Area (EA) }\end{array}$ & $\begin{array}{c}\text { Total } \\
\text { household }\end{array}$ \\
\hline $\begin{array}{l}\text { Census } \\
\text { Nepal Total }\end{array}$ & 75 & 40,659 & $5,423,297$ \\
$\begin{array}{l}\text { Mountain } \\
\text { belt }\end{array}$ & 16 & 4973 & 363,698 \\
$\begin{array}{l}\text { NLSS } \\
\text { Nepal Total } \\
\text { Mountain } \\
\text { belt }\end{array}$ & 71 & 499 & 5,988 \\
$\begin{array}{l}\text { (Extracted from population census } \\
\text { NLSS 2010/11 datasets) }\end{array}$ & & & 4011 \\
\hline
\end{tabular}

\section{Developing Explanatory Model and Estimation of Model Coefficients}

In multilevel modeling, effects of explanatory variables are decomposed into two different sources: fixed and random effect. In fixed effect model, model parameters are fixed or nonrandom. These generally include population attributes rather than entities. Random effect model is used when there is a reason to belief that differences across entities have influence on the dependent (outcome) variables (Torres-Reyna, 2007). It is generally assumed that there are different hierarchies of entities in which each lower level entity is nested in higher level of hierarchy. Considering cluster sample design of NLSS, EAs constituted primary sampling units (PSUs) from which a fixed number of entities (households) were selected. In this hierarchical nature of sampling, EAs constitute a higher level of unit within which households are nested. Generally, characteristics of EA are not the same as they come from large and diverse geographical areas of the country and difference in EA has some role to play in determining incidence of household poverty. Therefore, EA has been used as random effect variable in 
this exercise. This represents areaspecific random effect.

As indicated above, for the present study, logistic regression model with logit link function under GLMM that incorporate fixed and random effects constitute explanatory model for estimating model coefficients. The logit under the GLMM is estimated as linear combination of least square regression model with the following equation

$$
\ln \left[\frac{P_{i j}}{\left(1-P_{i j}\right)}\right]=\beta_{0 j}+\beta_{1 j} x_{i j}+z_{j} u_{j}+e_{i j}
$$

where,

\section{$\mathrm{i}=$ household}

$\mathrm{j}=$ groups disaggregated by the categories of the random effect variable, PSU

$\mathrm{P}_{\mathrm{ij}}=$ Probability of household $\mathrm{i}$ being poor in group $\mathrm{j}$.

$\ln \left[\frac{P_{i j}}{\left(1-P_{i j}\right)}\right]=\log$ odd for household $\mathrm{i}$ in group $\mathrm{j}$

$\beta_{\mathrm{oj}}=$ intercept for household $\mathrm{i}$ in group $\mathrm{j}$ who are poor

$\beta_{1 j}=$ regression coefficient associated with fixed variables for the $\mathrm{j}^{\text {th }}$ group

$\mathrm{x}_{\mathrm{ij}}=$ fixed effect variables for $\mathrm{i}^{\text {th }}$ household in group $\mathrm{j}$
$\mathrm{Z}_{\mathrm{j}}=$ area-specific random effect (intercept) associated with $\mathrm{u}_{\mathrm{j}}$ (=PSU)

$\mathrm{u}_{\mathrm{j}}=\mathrm{jth}$ PSU

$\mathrm{e}_{\mathrm{ij}}=$ error term

Since the purpose of this study is to estimate probabilities of being each household poor, the above equation is implemented to get logit score for each household. Therefore, the model is a unit level model.

The fixed effect variables $\left(\mathrm{x}_{\mathrm{ij}}\right)$ have been represented with the variables which are present in both NLSS and census data files and having similar definition. Initially, 16 fixed effect variables chosen and incorporated in the model. However, only 7 variables appeared to be statistically significant in explaining poverty (Table 2 ).

Categorical variables are coded as binary variables with " 0 " or " 1 ". Then model coefficients estimated with the help of STATA (ver. 15). It is to note here that developing an explanatory model is an iterative process. Exclusion and inclusion of a predictor variable in the model leads to changes in the explanatory power of the model as well as prediction errors. Hence, utmost care was taken to retain statistically 
170 | B. R. Suwal

significant predictors in the model which can predict household probabilities closely to the observed rates for the mountain belt and also yield lowest prediction errors.

\section{Model Validation}

An assessment of the predictive power of the model in terms of chi-square indicates that, compared to the constantonly model, predictive power of the model significantly improves with constant and variable model
(Chi2=87.69, Prob $>$ Chi2=0.000) (Table $2)$. Predictive power of the model can also be assessed in terms of ROC (Receiver Operating Characteristics) curve analysis by seeing the AUC (Area Under the Curve). AUC greater than 80 percent is generally considered highly satisfactory performance of the model (Rana at al., 2015). In this light, the explanatory model used to predict the household probabilities of being poor is found to be highly satisfactory with AUC of 87.31 percent with acceptable level of standard error, i.e. 0.0192 .

\section{Table 2}

Estimated Model Coefficients From Logit Model Under GLMM

\begin{tabular}{|c|c|c|c|c|c|}
\hline \multicolumn{6}{|c|}{ Wald Chi2(7) $=87.69($ Prob>Chi2: 0.000$)$} \\
\hline & & Robust & & & \\
\hline Predictor variables & Coef. & Std. Err. & $\mathrm{Z}$ & $\mathrm{P}>\mathrm{Z}$ & Variable description \\
\hline eastern & -1.126 & 0.414 & -2.72 & 0.006 & Region of residence: eastern region \\
\hline central & 1.472 & 0.450 & 3.27 & 0.001 & Region of residence: central region \\
\hline mobile & -1.509 & 0.366 & -4.13 & 0.000 & Have mobile phone in the household \\
\hline Brahman & -1.264 & 0.328 & -3.85 & 0.000 & Caste/ethnicity: Brahman caste \\
\hline popunder18 & 0.656 & 0.101 & 6.52 & 0.000 & $\begin{array}{l}\text { Number of family members under } 18 \\
\text { years of age }\end{array}$ \\
\hline $\begin{array}{l}\text { Above primary } \\
\text { education }\end{array}$ & -0.417 & 0.179 & -2.33 & 0.020 & $\begin{array}{l}\text { Number of family members with above } \\
\text { primary level of education }\end{array}$ \\
\hline Literate adults & 0.533 & 0.158 & 3.37 & 0.001 & Number of literate family members \\
\hline _cons & -1.396 & 0.453 & -3.08 & 0.002 & \\
\hline xhpsu & & & & & Primary sampling units (PSUs) \\
\hline $\operatorname{var}\left(\_\right.$cons $)$ & .286 & .177 & & & \\
\hline
\end{tabular}




\section{Prediction of Household Probabilities}

Once performance of model is evaluated, the estimated model coefficients have been simulated to the census data file (household file) to estimate logit score using "predict" command in STATA. The logit scores then were converted into household probabilities of being "poor" (with the estimated logistic regression function,

$$
\hat{P}_{i j}=\frac{e^{\hat{\alpha}+\hat{\beta} x_{i j}+z_{j} u_{j}}}{1+e^{\hat{\alpha}+\hat{\beta} x_{i j}+z_{j} u_{j}}}
$$

where, $\mathrm{e}=$ exponential $(=2.718281828)$

$$
\hat{\alpha}=\text { constant }
$$

$\hat{\beta}=$ estimated regression coefficients associated with fixed effect variables, $x_{i j}$

$\hat{\alpha}+\hat{\beta} x_{i j}=$ predicted logits

\section{Estimation of Mean} Probabilities

After prediction of household probabilities, proportion of population below poverty line for different caste/ethnic groups within each district is estimated as a mean of the household level predicted probabilities weighted by family size. The formula for estimating proportion of the population below poverty line consisting of $\mathrm{k}$ number of households of $i^{\text {th }}$ caste/ethnic group in each district (h) is estimated as

$$
\bar{P}_{i h}=\frac{\sum_{f=1}^{k} W_{f i h} * \widehat{P}_{f i h}}{\sum_{f=1}^{k} W_{f i h}}
$$

where,

$\widehat{\mathrm{P}}_{\mathrm{ih}}=$ Estimated mean proportion of the population below poverty line for caste/ethnic group i of district $\mathrm{h}$

$\mathrm{W}_{\text {fih }}=$ population weight (family size) for the household $\mathrm{f}$ of a caste/ethnic group $i$ of district $h$

$\sum \mathrm{W}_{\text {fih }}=$ sum of population weight (family size) for the household $\mathrm{f}$ of a caste/ethnic group i of district $\mathrm{h}$

The reference time for the estimated poverty rates is 2010/11 (almost 10 years earlier than now). However, given the slow pace of economic development of the country, it is assumed that incidence of poverty in Nepal as well as mountain belt has not much changed over the period and the estimated poverty rates will provide baseline data for all working on the agenda of social 
inclusion including local government. The sample size of 408 in NLSS 2010/11 for the mountain belt is believed to be large enough to capture underlying structure of the data in SAE exercise.

\section{Validation of Results}

The model has predicted a poverty rate of 40.67 for the mountain belt as a whole which is less only by 1.6 percentage points when compared with the observed poverty rate $(42.27 \%)$ estimated from NLSS 2010/11 for the same belt. The overall relative error defined as an average variability of predicted proportion $\left(\overline{\mathrm{P}}_{\mathrm{p}}\right)$ from the observed proportion $\left(\overline{\mathrm{P}}_{\mathrm{O}}\right)$, i. e. $\left[\left(\overline{\mathrm{P}}_{\mathrm{p}}-\overline{\mathrm{P}}_{\mathrm{o}}\right) / \overline{\mathrm{P}}_{\mathrm{o}}\right] * 100$, is estimated to be 3.79 percent. The corresponding estimates for Chhetree caste is 6.5 percent and other than Chhetree is 3 percent. $^{i}$ A significant test of the difference between overall predicted and observed proportion indicates that Z- score for the difference is -0.5692 . Since Z-score for the difference is within -2 and +2 , we can conclude that there is no serious problem of under/over fitting of the model (standard error for the estimated probabilities is calculated through bootstrapping of estimated probabilities). For this, same sample size of 408 used by the NLSS was selected with simple random sampling procedure from the auxiliary data after prediction.

Prediction error, generally defined as standard error of estimated proportion, is calculated by delta method following the guideline provided by Gutierr and Inlow. ${ }^{\text {ii }}$ Average prediction error of the estimated proportion for the mountain belt as a whole is estimated to be 6.57 percent. The highest prediction error is estimated to be 8.07 percent for Darchula district and the lowest for Sankhuwasabha (5.62\%). The prediction error for different caste/ethnic groups ranges lowest of 2.31 percent for Brahman-Hill of Sankhuwasabha district to the highest of 9.17 for Byasi/Sankha of Darchula district. Distribution of average prediction error over caste/ethnicity shows that average prediction error does not exceed 8 percent for the 92 percent of the caste/ethnicities. The amount of standard errors as estimated by CBS (2011) for poverty rate of Ilaka using linear models of SAE also show almost at similar level. 


\section{Results and Discussions}

This section presents results and discussions. Results and discussions are summarized under the two main headings: estimates of poverty rates, and spatial variation. In addition, estimates of total population below poverty line for each caste/ethnic group have also been provided. Appendix at the end provides detail results on the estimate of poverty and standard error of the estimates.

\section{Estimates of Poverty Rates}

There is a substantial variation in the incidence of poverty across the mountain districts with the lowest poverty rate of 21.65 in Sankhuwasabha (Province 1) and the highest of 69.31 percent in Bajhang (Province 7) district (Appendix). District level poverty rates tend to sharply increase when we move from eastern to western districts of mountain belt. By caste/ethnicity, poverty rate ranges minimum of 4-7 percent for Brahmin-Hill of three eastern districts (Taplejung, Sankhuwasabha and Solukhumbbu Province 1) and one western district (Mustang, Province 4) to maximum of 88 percent for Dalit (others) of Bajura district (Province 7). For large majority of the caste/ethnic groups (i.e. 80\%), poverty rates are estimated to be higher than national average (i.e. 25.16\%). Ranking of caste/ethnic group in each district based on poverty rates indicates that four caste groups namely BrahmanHill, Chhetree, Sanyasi/Dasnami, and Thakuri stand in 1st, 2nd and 3rd lowest rank in most of the districts. Among the four caste groups, poverty rate for Brahman-Hill is found to be the lowest in the largest number of 11 districts. However, it is to note that there is a substantial variation in the lowest range of poverty rate of the various caste/ethnic groups under study. For example, the lowest range of poverty rate in the three districts of eastern region (Taplejung, Sankhuwasabha and Solukhumbu - Province 1), does not exceed 15 percent while it is estimated to be very high (50-60\%) in the mid and far western mountain districts like Bajura, Bajhang and Darchula (Province 7).

Poverty rates further indicate that three Dalit castes - Kami, Damai/Dholi, and Sarki from western district (Manang \& Mustang - Province 4), mid-western districts (Dolpa, Jumla, Kalikot, Mugu, Humla districts - Province 6) and farwestern district (Bajura, Bajhang, Darchula - Province 7) including one 
174 | B. R. Suwal

district from central region (Rasuwa, Province 3) stand at the highest rank. These three caste groups have exceptionally high poverty rate in Bajura, Bajhang and Darchula Province 7) districts (86-88\%). Compared to this, poverty rate for these groups is also found to be substantially low (53-69\%) when moved to midwestern districts (Dolpa, Jumla, Kalikot, Mugu and Humla - Province 6). It further decreases to 34-40 percent when we move to the western districts (Rasuwa, Manang and Mustang). It is interesting to note that none of the Dalit castes from eastern (Taplejung, Sankhuwasabha, Solukhumbu) Province 1) and central districts (Dolakha, and Sindhupalchok Province 3) stand at the highest rank of poverty. In these districts, mix of Janajati groups stand at the highest rank. However, poverty rate of most of these Janajati groups (32-38\%), with the exception in Dolakha, corresponds with the three Dalit groups from Rasuwa (Province 3) (Manang and Mustang Province 4).

A quintile analysis of estimated poverty rates show that most of the caste/ethnicities belonging to the lowest quintile of the poverty rates are Brahman-Hill, Chhetree, Gurung and Newar (Tabulation not shown). They are mainly from eastern, central and western mountain districts (except Thakuri of Dolpa, Province 6) and Brahman-Hill of Jumla, Province 6). Contrary to this, most of the caste/ethnicities falling in the highest quintile of the poverty rates are Dalits (Sarki, Kami, Damai/Dholi Lohar, Badi, and Dalit others) from the mid and far western districts (Province $6 \quad \& \quad 7$ ). 


\section{Figure 1}

Estimated Poverty Rates for Major Caste/Ethnicities, Mountain Districts

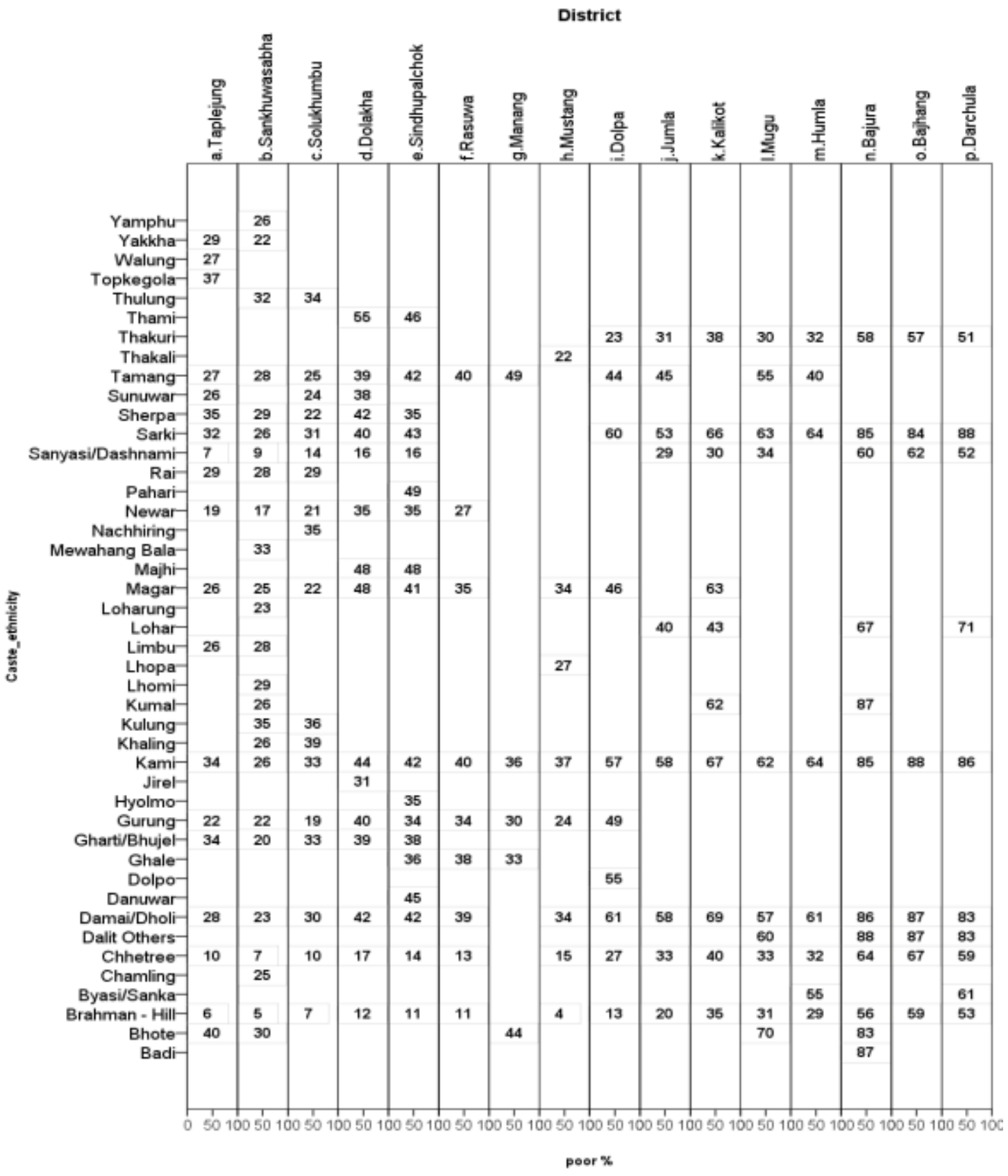

Social Inquiry: Journal of Social Science Research, Volume 2, Issue 2, 2020 


\section{Spatial Variation Caste/Ethnic Poverty}

When compared caste/ethnic poverty along the east-west continuum of the mountain districts, various spatial pattern of poverty distinct to different caste/ethnicities emerges. In general, it can be said that caste/ethnic poverty tends to increase when we move from eastern to the western part of the mountain belt. It is interesting to note that some castes/ethnicities with similar culture follow almost similar spatial pattern of poverty and form a cluster of districts in different regions with almost similar level of poverty rates. Therefore, based on the similarity of the level and spatial pattern of poverty rates, the following nine caste/ethnic groups can be classified into three groups as followings:

- Brahman-Hill, Chhetree, and Sanyasi /Dashnami (BCSD)

- Damai/Dholi, Kami, and Sarki (Dalits)

- Gurung, Tamang, Magar (GTM)

\section{Brahman-Hill, Chhetree, and Sanyasi/Dashnami (BCSD)}

Brahmin-Hill, Chhetree and Sanyasi/ Dashnami belong to hill caste group and generally known as socio-economically advanced groups. Poverty rates for these castes in the districts of eastern region (Taplejung, Sankhuwasabha and Solukhumbu - Province 1) is estimated to be the lowest (less than 10\%) which increases up to 16 percent in the districts of central region. It further increases to around 30 percent in the four districts of mid-western region (Humla, Mugu, Kalikot and Jumla Province 6) and to 60 percent with further increase in three districts of far western region (Bajura, Bajhang and Darchula - Province 7). By comparing poverty rates of the BCSD in different clusters of the districts with national average (i.e. $25.16 \%$ ), four major spatial patterns of poverty rates for the BCSD can be identified:

- The three mountain districts (Taplejung, Sankhuwasabha, and Solukhumbu - Province 1) have very low level of poverty rates $(<10 \%)$ than the national average.

- There is another cluster of districts in central and mid-western region (Dolakha, Sindhupalchok, Rasuwa, Manang and Mustang - Province 3 $\&$ 4) with slightly lower poverty rates (up to 20\%) than the national average.

- Five mid-western mountain districts form another cluster of districts with moderately high level of poverty 
(around 30\%) than the national average - Dolpa, Jumla, Kalikot, Mugu, and Humla (all from Province $6)$.
- Three far western mountain districts (Bajura, Bajhang and Darchula Province 7) form a cluster of districts with high level of poverty (around $60 \%$ ) than the national average.

\section{Figure 2}

Estimated Poverty Rates for Hill Brahmin, Chhetri, Sanysai/Dashnami \& Thakuri

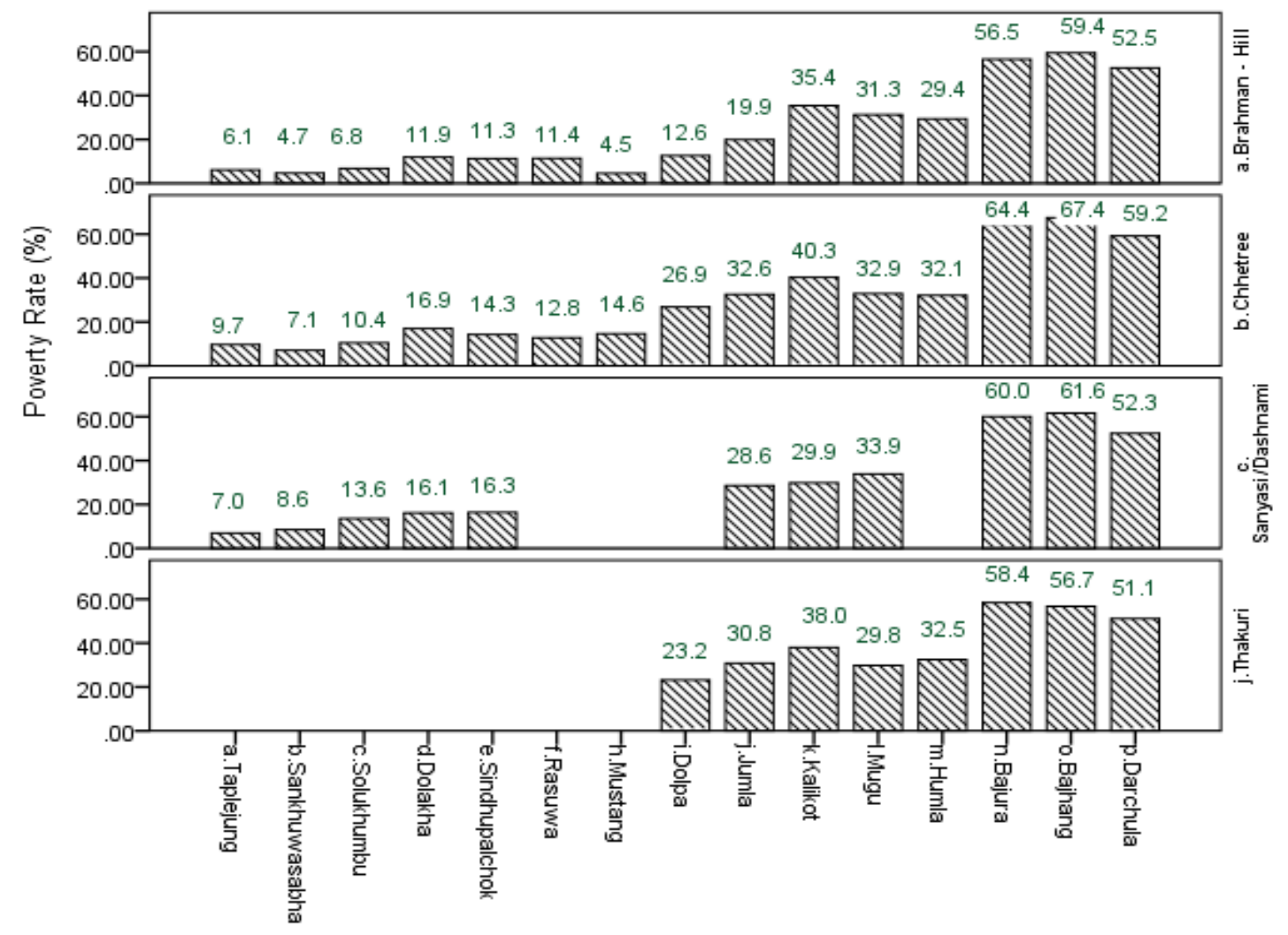

District

Damai/Dholi, Kami, and Sarki (Dalits)

Like BCSD, these three groups also belong to Hill caste groups and generally known as Dalits and socioeconomically backward communities. Like BCSD, Dalits from the three eastern districts (Taplejung, Sankhuwasabha, and Solukhumbu Province 1) also demonstrate the lowest poverty rates. But poverty rates of 
Dalits in these districts are much higher (23-34\%) than that of BCSD of the same districts. But it nearly corresponds with the BCSD of central and some western districts (Dolakha, Sindhupalchowk, Rasuwa, Manang and Mustang - Province 3 \& 4) (34-40\%). It further increases to around 60 percent in some of the mid-western districts ( Dolpa, Jumla, Kalikot, Mugu, Humla Province 6) with exceptionally high poverty rates for the three districts of far western region (Bajura, Bajhang, and Darchula - Province 7). By comparing poverty rates of Dalits in different clusters of districts with national average (i.e. $25.16 \%$ ), the following major spatial patterns of poverty of Dalits can be identified:

- There is no cluster of districts (except Sankhuwasabha, Province 1) in the case of Damai/Dholi) with poverty rates lower than the national average.

- Like BCSD, Dalits from three districts of eastern regions (Taplejung, Sankhuwasabha and Solukhumbu $\quad-$ Province 1) demonstrate lowest level of poverty. But poverty rates of Dalits in these districts are not much higher (around $30 \%$ ) than the national average. But it is much higher than that of BCSD $(<10 \%)$ of the same districts.

- When we move from eastern to central districts, poverty rates of Dalits increases to around 40 percent. Contrary to the general spatial pattern of poverty, it tends to decrease when we move to western districts (34-38\% in Manang and Mustang - Province 4).

- Poverty rates of Dalits further increases in mid-western region (Dolpa, Jumla, Kalikot, Mugu and Humla - Province 6) with around $60 \%$ of the population living below poverty line which is much higher incidence of poverty than the national average.

- The incidence of poverty among Dalits further increases to its highest level in the three districts of far western region (Bajura, Bajhang and Darchula - Province 7) with around 85 percent of poverty rate. 


\section{Figure 3}

\section{Estimated Poverty Rates for Damai/Dholi, Kami \& Sarki}

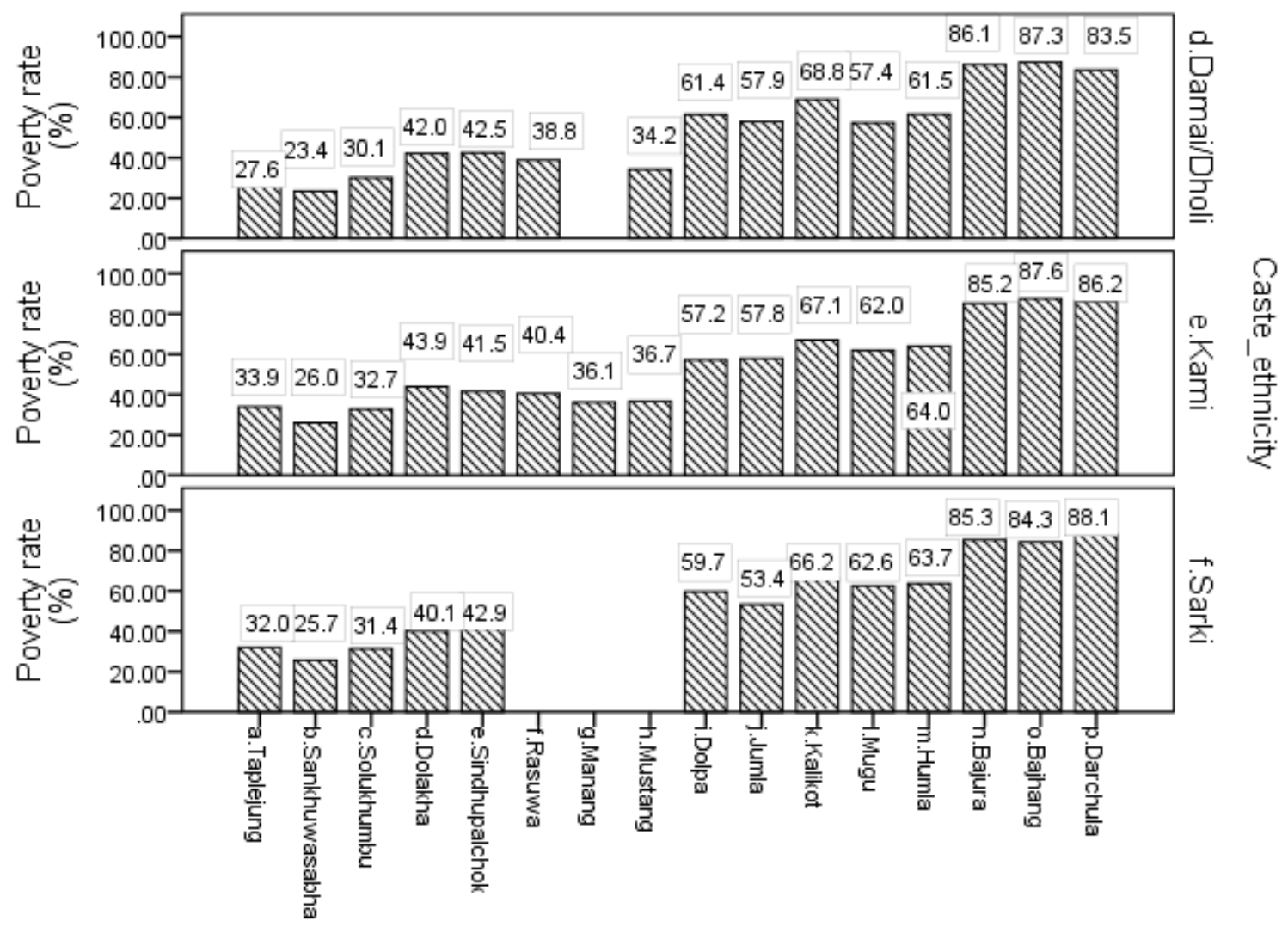

District

\section{Gurung, Magar, Tamang (GMT)}

GMT in Nepal are known as three major socioeconomically backward Janajati groups. However, these groups are generally known as more forward than the Dalits. Gurung and Magar each appears to be major groups in 9 mountain districts (out of 16), and Tamang in 11 districts. Figure 4 shows that these groups do not qualify as a major group in the districts of far western region (Province 7). Like BCSD and the Dalits, GMT residing in three eastern mountain districts have the lowest incidence of poverty (around $20 \%$ with slightly higher rates for Tamang) which nearly corresponds with the national poverty rates $(25.16 \%)$. But

Social Inquiry: Journal of Social Science Research, Volume 2, Issue 2, 2020 
GMT in these districts have lower poverty rates than that of Dalits (23$34 \%$ ), but substantially higher than that of BCSD $(<10 \%)$. GMT also demonstrates a higher level of poverty rates when we move from eastern to western part of the mountain belt. For example, poverty rates increase to 29-49 percent in most of the districts of central and western region (Province $3 \& 4$ ) and further increases to 63 percent in mid-western districts (Province 6). By comparing poverty rates of GMT in different cluster of districts with national average (i.e. $25.16 \%$ ), the following major spatial patterns of poverty rates of GMT can be identified:

- Unlike Dalits, there is a cluster of three districts in eastern region (Taplejung, Sankhuwasabha, Solukhumbu - Province 1) with poverty rates lower than/equal to the national average. Poverty rates for
GMT in these districts are much higher than that of BCSD and slightly lower than that of Dalits.

- GMT in the central region form a cluster of districts with remarkably higher poverty rates (34-48\%) than the national average. There is another such cluster of districts with mostly 40-63 percent of poverty rates in mid-western mountain (Dolpa, Jumla, Mugu, Kalikot, and Humla Province 6).

- Contrary to general spatial pattern of poverty, poverty rates of Gurung and Magar tend to be higher for the districts of central (around 40-48\%) than the western region (Province 4) (mostly 30-40\%). But, in the case of Tamang, it tends to increase from about 40 to 49 percent when we move from central to western region (Province 3 to 4 ). 


\section{Figure 4}

Estimated Povery Rates for Gurung, Tamang \& Magar

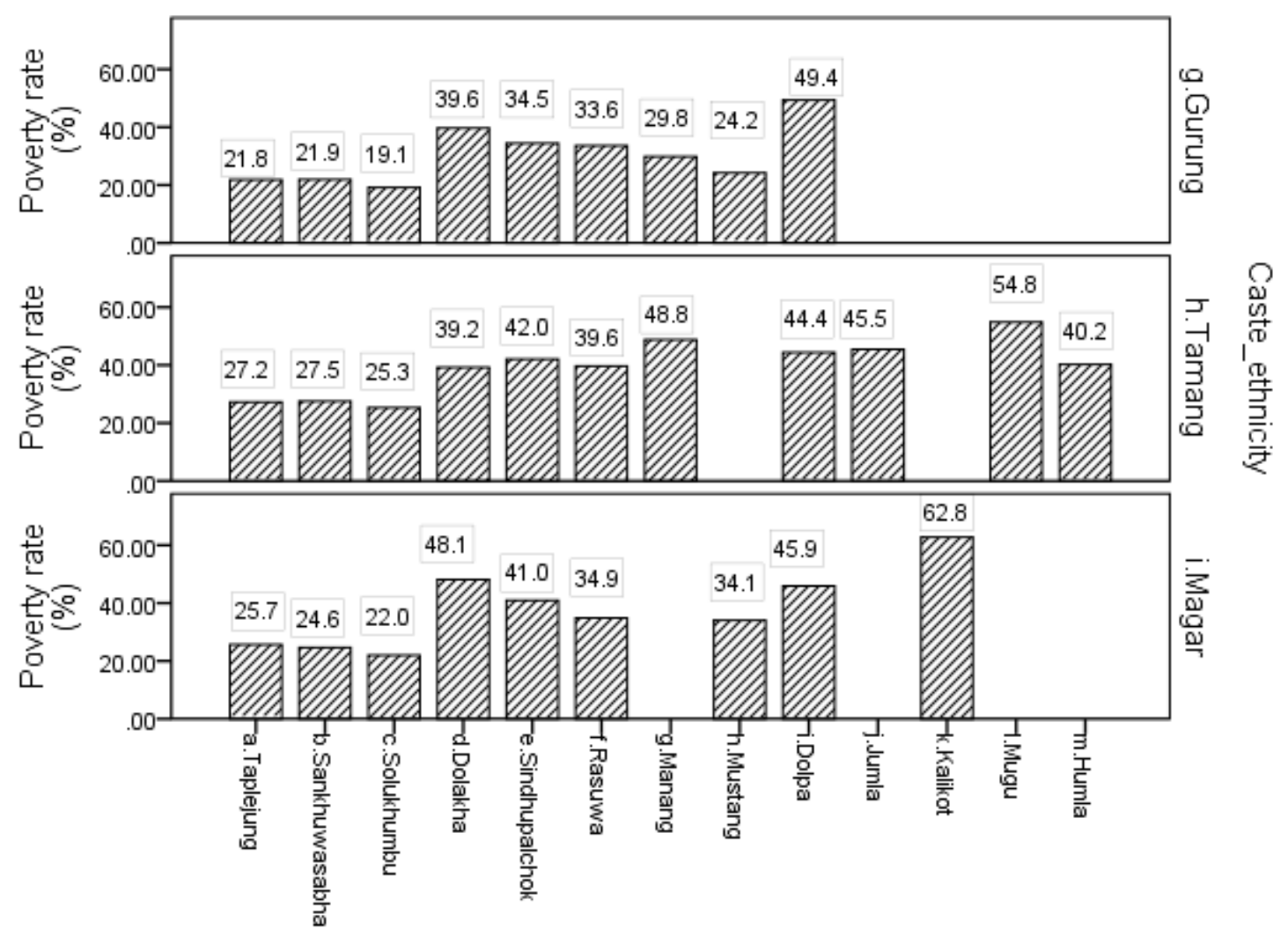

District

\section{Other Caste/Ethnic Groups}

Thakuri is another caste group included in the analysis from mid and far western mountain districts (Province $6 \& 7$ ). Thakuri is known as one of the socioeconomically forward groups in Nepal. Thakuri residing all the districts of mid and far western mountain (except Dolpa) demonstrates poverty rates higher than the national average. Considering the similarity of poverty rates in different districts, two clusters of districts for Thakuri can be identified - one in mid-western region where poverty rates of Thakuri range in between 23-38 percent and another in 
far western region where poverty rate ranges in between 51-58 percent.

The other Janajati groups which appear major groups in the 3-6 districts of eastern and central mountain region (Province $1 \&$ 3) such as Sunuwar, Rai, Newar, Gharti/Bhujel do not differ much in terms of incidence of poverty. Nevertheless, some increase in poverty rates when we move from the districts of eastern to central regions is seen particularly in Sunuwar $(26 \%$ in Taplejung (Province 1) to $38 \%$ in Dolakha (Province 3), Newar (19\% in Taplejung to $35 \%$ in Dolakha), Gharti/Bhujel (34\% in Sankhuwasabha to $38-39 \%$ in Sindhupalchowk and Dolakha (all from Province 3). Another case in point is Lohar which appears to be a major Dalit caste in each one district of mid and far western mountain also demonstrates substantial increase in the poverty rates when we move from mid-western (Province 6) (around 40\%) to far western districts (Province 7) (around $71 \%$ ). Kumal appears to be major Janajati group in one of the eastern mountain districts (Sankhuwasabha, Province 1) and each one district of mid-west (Kalikot, Province 6) and far west mountain (Bajura, Province 7). Like other caste/ethnic groups, poverty rate of
Kumal substantially increases when we move from Sankhuwasabha (Province 1) $(26 \%)$ to the western and far western mountain districts $(62 \%$ in Kalikot, Province 6 and $87 \%$ in Bajura, Province 7 ). The poverty rate of Bhote Janajati group also substantially increases when considered east to west continuum of the districts (30-40\% in Sankhuwasabha - Province 1, Taplejung - Province 1, and $87 \%$ in Bajura - Province 7).

\section{Estimates of Population below Poverty Line}

The estimates show that the 44 castes/ethnicities accounted for 718 thousands population living below poverty line in mountain belt (Table 3 ). Of them, Chhetree caste alone accounted for the largest 38 percent (or 270 thousands). This is followed by Tamang (11.23\% or 80 thousands) and Kami (10.34\% or 74 thousands). Although incidence of poverty among Brahman-Hill is the lowest in most of the districts (Appendix), this caste stands in fourth position in terms of the size of the population below poverty line ( $6.84 \%$ or 49 thousands). Thakuri with 34 thousands population below poverty line deserves fifth position. When castes/ethnicities are classified into three broad groups - 
Brahman/Chhetree (includes Thakuri \& Sanyasi/Dashnami), Janajatis, and Dalits - Brahman/Chhetree accounted for 50 percent (or 361 thousands) of the total population below poverty line, Janajatis 30 percent (or 218 thousands) and Dalits 19 percent (or 138 thousands).

Considering spatial concentration of five largest caste/ethnicities in terms of the size of population below poverty line, large majority of the Chhetree population living below poverty line (70\%) is concentrated in three districts of far western region (Bajura, Bajhang and Darchula - Province 7) (Table 3) where poverty rate is estimated to be the highest for Chhetree (around 60\%) (Appendix). Likewise, in the case of Tamang, 82 percent of the population below poverty line comes from three districts of central region (Dolakha, Sindhupalchok and Rawuwa - Province 3). Poverty rate for Tamang in these districts is estimated to be around 40 percent (Appendix). Contrary to Chhetree and Tamang, Kami which deserves third position in terms of the size of population below poverty line shows more uniform distribution of the population below poverty line across different districts with the highest 54 percent in one mid-western district
(Kalikot, Province 6) and two far western districts (Bajura and Bajhang Province 7). The other $4 \mathrm{mid}$ and far western districts (Humla, Mugu, Jumla and Darchula - Province 6), and two central districts (Dolakha and Sindhupalchok - Province 3) accounted for 4-8 percent of the total Kami population living below poverty line. In the case of Brahman-Hill, 76 percent of the population below poverty line come from one mid-western district (Kalikot, Province 6) and three far western districts (Bajura, Bajhang and Darchula - Province 7). Likewise, large majority of the total Thakuri population living below poverty line $(84 \%)$ comes from five mid and far western districts (Humla, Kalikot, Bajhang, Bajura and Darchula - Province 6 \& 7).

In addition to the above the five caste/ethnic groups, Damai/Dholi and Sarki are other two most common Dalit castes found in the mountain districts. Although these groups demonstrate highest incidence of poverty in most of the districts (Appendix), Sarki stands in sixth and Damai/Dholi in seventh position in terms of the size of population below poverty line. For these two Dalit groups, around 80 percent of the population below poverty line comes from 6 central, mid-western and 
184 | B. R. Suwal

far western districts (Dolakha, Sindhupalchok, Kalikot, Jumla, Bajura and Bajhang - Province 3, 6 \& 7). In the case of Newar, nearly 90 percent of the population below poverty line are from two central districts (Dolakha and Sindhupalchok - Province 3). On the contrary, Sherpa shows much more uniform distribution of the population below poverty line across the three eastern and two central districts (Sankhuwasabha, Solukhumbu, Taplejung, Dolakha and Sindhupalchok - Province 1 \& 3). Percent of Sherpa population below poverty line in these districts range in between 15-24. (Appendix). Ethnic groups like Limbu (85\% in Taplejung, Rai $(38 \%$ in Sankhuwasabha, and $48 \%$ in Solukhumbu - all from Province 1) and Thami $(80 \%$ in Dolakha, Province 3) have high concentration of population below poverty line in one or two districts. Nearly 90 percent of the population below poverty line for Magar comes from two eastern (Solukhumbu and Sankhuwasabha -
Province 1), two central (Dolakha and Sindhupalchok - Province 3) and one mid-western (Dolpa, Province 6) districts. Likewise, nearly 81 percent of the Gurung population below poverty line come from two eastern (Taplejung and Sankhuwasabha - both from Province 1), one central (Sindhupalchok, Province 3), one western (Manang) and one mid-western (Dolpa, Province 6) districts. Sanyasi/Dashnami which is included in the analysis from 11 districts demonstrates 80 percent of its population below poverty line concentrated in one central (Sindhupalchowk, Province 3) and three far western (Bajura, Bajhang and Darchula - Province 7) districts. For the remaining caste/ethnic groups (ranked as 17-44, Table 3) included in the analysis, population below poverty line comes from 1-5 districts (Appendix). 


\section{Table 3}

Estimated Population Living Below Poverty Line

\begin{tabular}{|c|c|c|c|c|c|c|c|c|c|}
\hline SN & Caste/ethnicity & $\begin{array}{l}\text { Estimated } \\
\text { population } \\
\text { below } \\
\text { poverty line }\end{array}$ & Percent & Rank & $\mathrm{SN}$ & Caste/ethnicity & $\begin{array}{l}\text { Estimated } \\
\text { population } \\
\text { below } \\
\text { poverty } \\
\text { line }\end{array}$ & Percent & Rank \\
\hline 1 & Chhetree & 270,148 & 37.62 & 1 & 23 & Byasi/Sanka & 1,965 & 0.27 & 23 \\
\hline 2 & Tamang & 80,657 & 11.23 & 2 & 24 & Hyolmo & 1,694 & 0.24 & 24 \\
\hline 3 & Kami & 74,235 & 10.34 & 3 & 25 & Yakkha & 1,686 & 0.23 & 25 \\
\hline 4 & Brahman - Hill & 49,102 & 6.84 & 4 & 26 & Danuwar & 1,661 & 0.23 & 26 \\
\hline 5 & Thakuri & 34,826 & 4.85 & 5 & 27 & Badi & 1,642 & 0.23 & 27 \\
\hline 6 & Sarki & 23,574 & 3.28 & 6 & 28 & Jirel & 1,429 & 0.20 & 28 \\
\hline 7 & Damai/Dholi & 23,530 & 3.28 & 7 & 29 & Nachhiring & 1,320 & 0.18 & 29 \\
\hline 8 & Newar & 19,893 & 2.77 & 8 & 30 & Sunuwar & 1,148 & 0.16 & 30 \\
\hline 9 & Sherpa & 17,260 & 2.40 & 9 & 31 & Yamphu & 1,118 & 0.16 & 31 \\
\hline 10 & Limbu & 16,338 & 2.28 & 10 & 32 & Kumal & 1,081 & 0.15 & 32 \\
\hline 11 & Dalit Others & 15,315 & 2.13 & 11 & 33 & Pahari & 937 & 0.13 & 33 \\
\hline 12 & Rai & 12,714 & 1.77 & 12 & 34 & Ghale & 762 & 0.11 & 34 \\
\hline 13 & Thami & 11,418 & 1.59 & 13 & 35 & Mewahang Bala & 754 & 0.11 & 35 \\
\hline 14 & Magar & 9,104 & 1.27 & 14 & 36 & Lhopa & 609 & 0.08 & 36 \\
\hline 15 & Gurung & 8,016 & 1.12 & 15 & 37 & Thakali & 591 & 0.08 & 37 \\
\hline 16 & Sanyasi/Dashnami & 7,527 & 1.05 & 16 & 38 & Thulung & 585 & 0.08 & 38 \\
\hline 17 & Kulung & 6,806 & 0.95 & 17 & 39 & Topkegola & 524 & 0.07 & 39 \\
\hline 18 & Lohar & 5,436 & 0.76 & 18 & 40 & Walung & 304 & 0.04 & 40 \\
\hline 19 & Majhi & 3,381 & 0.47 & 19 & 41 & Lhomi & 256 & 0.04 & 41 \\
\hline 20 & Gharti/Bhujel & 3,052 & 0.43 & 20 & 42 & Khaling & 249 & 0.03 & 42 \\
\hline 21 & Bhote & 2,838 & 0.40 & 21 & 43 & Loharung & 222 & 0.03 & 43 \\
\hline \multirow[t]{2}{*}{22} & Dolpo & 2,244 & 0.31 & 22 & 44 & Chamling & 84 & 0.01 & 44 \\
\hline & & & & & & Total & 718,033 & 100.00 & \\
\hline
\end{tabular}

(Source: Appendix)

\section{Conclusion}

Available data from the past studies indicate that mountain belt, as compared to the hills and Tarai, has the highest incidence of poverty implying lowest economic condition of mountain people. This study further shows that, as expected, three socioeconomically advanced caste groups (Brahman, Chhetree and Sanyasi/Dashnami) have the lowest incidence of poverty in almost all the districts of mountain belt. Despite this, these three caste groups from mid and far western regions have much higher incidence of poverty than that of socioeconomically backward communities like Dalits and Janajatis from eastern and central regions. The three far western districts (Bajura, Bajhang and Darchula - Province 7) form a cluster of districts with very high incidence of poverty for Dalits as well 
as Brahman, Chhetree and Sanyasi/Dashnami. In fact, only a small fraction of Dalits in these districts are estimated to be above poverty line. However, the three economically forward caste groups in these districts demonstrate much better economic position than Dalits.

Janajatis, which have high concentration in the districts of eastern, central, and western regions (Province $1,3 \& 4)$, demonstrate an intermediate position in terms of incidence of poverty without much variation with Dalits. When considered poverty in absolute terms, caste/ethnic groups with larger population size also have larger size of population below poverty line with the largest number of such population in Chhetree caste from three districts of far west. The largest five caste/ethnic groups - Chhetree, Tamang, Kami, Brahman-Hill, Thakuri constitute the largest number of the total population below poverty line. Of them, Chhetree accounted for the largest number of population below poverty line.

This study confirms that with few exceptions incidence of poverty of all the castes/ ethnicities in mountain districts tends to increase along east to west continuum of the districts. In this continuum, three eastern mountain districts (Taplejung, Sankhuwasabha and Solukhumbu - Province 1) can be designated as the districts with lowest incidence of poverty for almost all the caste/ethnicities and the three far western districts (Bajura, Bajhang and Darchula - Province 7) with highest incidence of poverty. The range of highest and lowest poverty rates between the eastern and far western districts is substantial implying substantial variation in the economic position of the people between these areas. When compared incidence of poverty of same caste/ethnic group along the east-west continuum, some culturally similar groups show almost similar spatial pattern of poverty. The fact that incidence of poverty of these culturally similar groups tends to increase along the east-west continuum forming clusters of districts in each regional belt with almost similar level of poverty levels. This implies that incidence of poverty of culturally similar groups in mountain belt varies in similar ways along the east-west continuum of districts and it does not vary much within the regional cluster of the districts. 


\section{Disclosure Statement}

The author declares that no potential conflict of interest exists.

\section{Notes}

i. Only the sample size of Chhetree exceeds 100. So, observed rate for Chhetree is ii. calculated separately.

https://www.stata.com/support/faqs/stati stics/standard-error-predictedprobability/

\section{References}

Australian Bureau of Statistics. (2006). A guide to small area estimation Version 1.1. http://nss.gov.au/nss/home.NSF/533 222ebfd5ac03aca25711000044c9e/ 3a60738d0abdf98cca2571ab002426 64/\$FILE/May\%2006.pdf

Bolker, B. M., Brooks, M. E., Clark, C. J., Geange, S. W., Poulsen, J. R., Stevens, M. H. H., \& White, J. S. (2008). Generalized mixed models: A practical guide for ecology and evolution (Review). Trends in Ecology and Evolution, 24(3), 127135. https://doi.org/fwwbzr
Central Bureau of Statistics. (2005). Poverty trends in Nepal (1995-96 and 2003-04).

Central Bureau of Statistics. (2010/11). Poverty in Nepal 2010/11.

Central Bureau of Statistics. (2011). Small area estimation of poverty in Nepal (in Nepali).

Central Bureau of Statistics. (2014). Population monograph of Nepal (Vols. I-III).

Chandra, H., Chambers, R., \& Salvati, N. (2009). Small area estimation of proportions in business Surveys [Working Paper 15-09]. Centre for Statistical and Survey Methodology, University of Wollongong. http://ro.uow.edu.au/cssmwp/35

Ghosh, M., \& Rao, J. N. K. (1994). Small area estimation: An appraisal. Statistical Science, 9(1), 55-93.

Goli, S., Maurya, N. K., Moradhvaj \& Bhandari, P. (2019). Regional differentials in multidimensional poverty in Nepal: Rethinking dimensions and method of computation.

https://doi.org/10.1177\%2F2158244 $\underline{019837458}$

Government of Nepal. (2018). Multidimensional poverty index: Analysis towards action. National Planning Commission. 
Hofmann D. A., Griffin, M. A. and Gavin, M. B. (2000). The application of hierarchical linear modeling to management research. In K. J. Klein, \& S. W. J. Kozlowski (Eds.), Multilevel theory, research, and methods in organizations. https://unc.live/2TLsWOx

Jia, H., Peter, M., \& Elaine, B. (2004). Comparison of small-area analysis techniques for estimating countylevel outcomes. American Journal of Preventive Medicine, 26(5), 453460.

National Planning Commission. (2018). Nepal: Multi-dimensional poverty index: Analysis towards action.

Rana, S., Midi, H., \& Sarkar, S. K. (2015). Validation and performance analysis of binary logistic regression model. Proceedings of the WSEAS International Conference on Environment, Medicine and Health Sciences.

Robinson, G. K. (1991). The BLUP is a good thing: The estimation of random effects. Statistical Science, 6(1), 15-51.

Torres-Reyna, O. (2007). Panel data analysis: Fixed and Radom Effects using Stata (v. 4.2) [PowerPoint slides]. https://bit.ly/35PwfK4

Tzavidis, N. (2013). Small area estimation: An appraisal
[PowerPoint slides]. https://bit.ly/3oQNinJ

United Nations Development Programme. (2009). Nepal human development report 2009: State transformation and human development.

United Nations Development Programme. (2010). Human development report 2010: The real wealth of nations: Pathways to human development. Palgrave Macmillan.

United Nations Development Programme. (2014). Nepal human development report 2014: Beyond geography: Unlocking human potential.

Woltman, H., Feldstain, A., Mackay, C., \& Rocchi, M. (2012). An introduction to hierarchical linear modeling. Tutorials in Quantitative Methods for Psychology, 8(1), 5259.

Zhang, S. (2016). Small area estimates: an illustration for family planning using Nepal as a case study [Illustration slides]. https://bit.ly/360DOOc

Social Inquiry: Journal of Social Science Research, Volume 2, Issue 2, 2020 


\section{Appendix}

\section{Estimates of Total Population, Poverty Rate, Standard Error and Population below}

\section{Poverty Line}

\begin{tabular}{|c|c|c|c|c|c|c|}
\hline Region & District & $\begin{array}{l}\text { Province/ } \\
\text { Caste_ethnicity }\end{array}$ & $\begin{array}{r}\text { Estimated } \\
\text { total } \\
\text { population }\end{array}$ & $\begin{array}{l}\text { Estimated } \\
\text { poverty rates } \\
(\%)\end{array}$ & $\begin{array}{l}\text { Standard } \\
\text { error of } \\
\text { poverty } \\
\text { rates }\end{array}$ & $\begin{array}{l}\text { Estimated } \\
\text { population below } \\
\text { poverty line }\end{array}$ \\
\hline For districts & & - & & & & \\
\hline Eastern & Taplejung & Province 1 & 127,607 & 23.76 & 5.94 & 30318 \\
\hline Eastern & Sankhuwasabha & Province 1 & 159,672 & 21.65 & 5.62 & 34566 \\
\hline Eastern & Solukhumbu & Province 1 & 106,083 & 24.06 & 6.14 & 25529 \\
\hline Central & Dolakha & Province 3 & 186,796 & 30.40 & 6.18 & 56778 \\
\hline Central & Sindhupalchok & Province 3 & 288,390 & 31.80 & 6.47 & 91694 \\
\hline Central & Rasuwa & Province 3 & 42,519 & 34.01 & 6.79 & 14461 \\
\hline Western & Manang & Province 4 & 5,880 & 32.01 & 7.72 & 1882 \\
\hline Western & Mustang & Province 4 & 11,699 & 25.63 & 6.54 & 2998 \\
\hline Mid western & Dolpa & Province 6 & 36,459 & 38.01 & 6.67 & 13857 \\
\hline Mid western & Jumla & Province 6 & 108,480 & 35.21 & 6.25 & 38200 \\
\hline Mid western & Kalikot & Province 6 & 137,839 & 46.07 & 6.65 & 63497 \\
\hline Mid western & Mugu & Province 6 & 55,335 & 39.94 & 6.45 & 22103 \\
\hline Mid western & Humla & Province 6 & 50,391 & 39.15 & 6.29 & 19728 \\
\hline Far western & Bajura & Province 7 & 135,384 & 68.39 & 7.21 & 92590 \\
\hline Far western & Bajhang & Province 7 & 196,486 & 69.31 & 7.19 & 136181 \\
\hline \multirow[t]{2}{*}{ Far western } & Darchula & Province 7 & 133,699 & 60.36 & 8.07 & 80706 \\
\hline & Total & & $1,782,719$ & 40.67 & 6.57 & 725088 \\
\hline \multicolumn{7}{|c|}{ For major caste/ethnicites } \\
\hline Eastern & a.Taplejung & Brahman - Hill & 9949 & 6.07 & 2.81 & 604 \\
\hline Eastern & a.Taplejung & Sanyasi/Dashnami & 955 & 6.96 & 3.06 & 66 \\
\hline Eastern & a.Taplejung & Chhetree & 15145 & 9.66 & 3.87 & 1462 \\
\hline Eastern & a.Taplejung & Newar & 1998 & 18.89 & 5.47 & 377 \\
\hline Eastern & a.Taplejung & Gurung & 5850 & 21.79 & 5.83 & 1275 \\
\hline Eastern & a.Taplejung & Magar & 1230 & 25.67 & 6.50 & 316 \\
\hline Eastern & a.Taplejung & Limbu & 53160 & 26.08 & 6.36 & 13862 \\
\hline Eastern & a.Taplejung & Sunuwar & 1380 & 26.11 & 6.65 & 360 \\
\hline Eastern & a.Taplejung & Walung & 1144 & 26.53 & 7.79 & 304 \\
\hline Eastern & a.Taplejung & Tamang & 5629 & 27.19 & 6.53 & 1531 \\
\hline Eastern & a.Taplejung & Damai/Dholi & 1863 & 27.61 & 6.90 & 514 \\
\hline Eastern & a.Taplejung & Rai & 6451 & 28.54 & 7.03 & 1841 \\
\hline Eastern & a.Taplejung & Yakkha & 271 & 28.90 & 7.34 & 78 \\
\hline Eastern & a.Taplejung & Sarki & 1195 & 32.00 & 6.97 & 382 \\
\hline Eastern & a.Taplejung & Gharti/Bhujel & 512 & 33.84 & 6.97 & 173 \\
\hline Eastern & a.Taplejung & Kami & 5997 & 33.89 & 7.24 & 2032 \\
\hline Eastern & a.Taplejung & Sherpa & 12081 & 34.57 & 7.19 & 4177 \\
\hline Eastern & a.Taplejung & Topkegola & 1403 & 37.35 & 8.22 & 524 \\
\hline Eastern & a.Taplejung & Bhote & 498 & 40.01 & 8.20 & 199 \\
\hline Eastern & b.Sankhuwasabha & Brahman - Hill & 8474 & 4.66 & 2.31 & 395 \\
\hline Eastern & b.Sankhuwasabha & Chhetree & 29248 & 7.12 & 3.14 & 2082 \\
\hline Eastern & b.Sankhuwasabha & Sanyasi/Dashnami & 1062 & 8.55 & 3.86 & 91 \\
\hline Eastern & b.Sankhuwasabha & Newar & 7582 & 16.52 & 5.01 & 1253 \\
\hline Eastern & b.Sankhuwasabha & Gharti/Bhujel & 855 & 19.54 & 5.76 & 167 \\
\hline Eastern & b.Sankhuwasabha & Gurung & 8731 & 21.89 & 5.88 & 1912 \\
\hline Eastern & b.Sankhuwasabha & Yakkha & 7295 & 22.04 & 5.91 & 1608 \\
\hline Eastern & b.Sankhuwasabha & Loharung & 969 & 22.91 & 6.13 & 222 \\
\hline Eastern & b.Sankhuwasabha & Damai/Dholi & 3511 & 23.40 & 6.24 & 822 \\
\hline
\end{tabular}




\begin{tabular}{|c|c|c|c|c|c|c|}
\hline Region & District & $\begin{array}{l}\text { Province/ } \\
\text { Caste_ethnicity }\end{array}$ & $\begin{array}{r}\text { Estimated } \\
\text { total } \\
\text { population }\end{array}$ & $\begin{array}{l}\text { Estimated } \\
\text { poverty rates } \\
(\%)\end{array}$ & $\begin{array}{l}\text { Standard } \\
\text { error of } \\
\text { poverty } \\
\text { rates }\end{array}$ & $\begin{array}{l}\text { Estimated } \\
\text { population below } \\
\text { poverty line }\end{array}$ \\
\hline Eastern & b.Sankhuwasabha & Magar & 5299 & 24.64 & 6.29 & 1306 \\
\hline Eastern & b.Sankhuwasabha & Chamling & 337 & 24.79 & 6.85 & 84 \\
\hline Eastern & b.Sankhuwasabha & Sarki & 2035 & 25.68 & 6.11 & 523 \\
\hline Eastern & b.Sankhuwasabha & Yamphu & 4323 & 25.85 & 6.43 & 1118 \\
\hline Eastern & b.Sankhuwasabha & Kami & 7589 & 25.95 & 6.61 & 1970 \\
\hline Eastern & b.Sankhuwasabha & Kumal & 900 & 25.96 & 6.82 & 234 \\
\hline Eastern & b.Sankhuwasabha & Khaling & 464 & 26.24 & 6.62 & 122 \\
\hline Eastern & b.Sankhuwasabha & Tamang & 16666 & 27.52 & 6.52 & 4587 \\
\hline Eastern & b.Sankhuwasabha & Limbu & 8752 & 28.29 & 6.61 & 2476 \\
\hline Eastern & b.Sankhuwasabha & Rai & 17017 & 28.32 & 6.64 & 4820 \\
\hline Eastern & b.Sankhuwasabha & Sherpa & 9356 & 29.17 & 6.84 & 2729 \\
\hline Eastern & b.Sankhuwasabha & Lhomi & 876 & 29.26 & 7.35 & 256 \\
\hline Eastern & b.Sankhuwasabha & Bhote & 3521 & 30.18 & 7.34 & 1063 \\
\hline Eastern & b.Sankhuwasabha & Thulung & 666 & 32.40 & 7.16 & 216 \\
\hline Eastern & b.Sankhuwasabha & Mewahang Bala & 2302 & 32.74 & 7.48 & 754 \\
\hline Eastern & b.Sankhuwasabha & Kulung & 9807 & 34.69 & 7.50 & 3402 \\
\hline Eastern & c.Solukhumbu & Brahman - Hill & 4897 & 6.79 & 2.90 & 333 \\
\hline Eastern & c.Solukhumbu & Chhetree & 15890 & 10.44 & 3.92 & 1659 \\
\hline Eastern & c.Solukhumbu & Sanyasi/Dashnami & 783 & 13.59 & 4.86 & 106 \\
\hline Eastern & c.Solukhumbu & Gurung & 781 & 19.13 & 5.65 & 149 \\
\hline Eastern & c.Solukhumbu & Newar & 2585 & 20.66 & 5.63 & 534 \\
\hline Eastern & c.Solukhumbu & Sherpa & 17795 & 21.96 & 5.92 & 3908 \\
\hline Eastern & c.Solukhumbu & Magar & 5251 & 21.97 & 6.36 & 1154 \\
\hline Eastern & c.Solukhumbu & Sunuwar & 317 & 23.88 & 6.27 & 76 \\
\hline Eastern & c.Solukhumbu & Tamang & 10480 & 25.34 & 6.69 & 2655 \\
\hline Eastern & c.Solukhumbu & Rai & 20812 & 29.08 & 6.96 & 6053 \\
\hline Eastern & c.Solukhumbu & Damai/Dholi & 1600 & 30.15 & 7.20 & 482 \\
\hline Eastern & c.Solukhumbu & Sarki & 557 & 31.36 & 7.36 & 175 \\
\hline Eastern & c.Solukhumbu & Gharti/Bhujel & 1981 & 32.58 & 7.32 & 645 \\
\hline Eastern & c.Solukhumbu & Kami & 5941 & 32.72 & 7.44 & 1944 \\
\hline Eastern & c.Solukhumbu & Thulung & 1093 & 33.77 & 7.51 & 369 \\
\hline Eastern & c.Solukhumbu & Nachhiring & 3737 & 35.32 & 7.46 & 1320 \\
\hline Eastern & c.Solukhumbu & Kulung & 9498 & 35.84 & 7.67 & 3404 \\
\hline Eastern & c.Solukhumbu & Khaling & 330 & 38.54 & 7.30 & 127 \\
\hline Central & d.Dolakha & Brahman - Hill & 17168 & 11.90 & 3.95 & 2043 \\
\hline Central & d.Dolakha & Sanyasi/Dashnami & 1342 & 16.12 & 4.67 & 216 \\
\hline Central & d.Dolakha & Chhetree & 62428 & 16.91 & 4.65 & 10556 \\
\hline Central & d.Dolakha & Jirel & 4559 & 31.33 & 6.89 & 1429 \\
\hline Central & d.Dolakha & Newar & 17644 & 35.20 & 7.34 & 6212 \\
\hline Central & d.Dolakha & Sunuwar & 1880 & 37.87 & 7.47 & 712 \\
\hline Central & d.Dolakha & Tamang & 31416 & 39.19 & 7.53 & 12313 \\
\hline Central & d.Dolakha & Gharti/Bhujel & 2703 & 39.21 & 7.32 & 1060 \\
\hline Central & d.Dolakha & Gurung & 999 & 39.65 & 7.83 & 396 \\
\hline Central & d.Dolakha & Sarki & 4074 & 40.12 & 7.38 & 1635 \\
\hline Central & d.Dolakha & Damai/Dholi & 4154 & 42.04 & 7.60 & 1746 \\
\hline Central & d.Dolakha & Sherpa & 8958 & 42.48 & 7.48 & 3805 \\
\hline Central & d.Dolakha & Kami & 8000 & 43.91 & 7.63 & 3513 \\
\hline Central & d.Dolakha & Magar & 2983 & 48.09 & 7.72 & 1435 \\
\hline Central & d.Dolakha & Majhi & 435 & 48.50 & 7.40 & 211 \\
\hline Central & d.Dolakha & Thami & 16740 & 54.75 & 7.61 & 9164 \\
\hline Central & e.Sindhupalchok & Brahman - Hill & 29791 & 11.27 & 4.03 & 3358 \\
\hline Central & e.Sindhupalchok & Chhetree & 52239 & 14.28 & 4.47 & 7462 \\
\hline Central & e.Sindhupalchok & Sanyasi/Dashnami & 10506 & 16.34 & 4.87 & 1717 \\
\hline Central & e.Sindhupalchok & Gurung & 2894 & 34.46 & 7.74 & 997 \\
\hline
\end{tabular}


Spatial Variation of Caste/Ethnic Poverty | 191

\begin{tabular}{|c|c|c|c|c|c|c|}
\hline Region & District & $\begin{array}{l}\text { Province/ } \\
\text { Caste_ethnicity }\end{array}$ & $\begin{array}{r}\text { Estimated } \\
\text { total } \\
\text { population }\end{array}$ & $\begin{array}{l}\text { Estimated } \\
\text { poverty rates } \\
(\%)\end{array}$ & $\begin{array}{l}\text { Standard } \\
\text { error of } \\
\text { poverty } \\
\text { rates }\end{array}$ & $\begin{array}{l}\text { Estimated } \\
\text { population below } \\
\text { poverty line }\end{array}$ \\
\hline Central & e.Sindhupalchok & Hyolmo & 4878 & 34.72 & 7.07 & 1694 \\
\hline Central & e.Sindhupalchok & Newar & 32193 & 34.95 & 7.62 & 11253 \\
\hline Central & e.Sindhupalchok & Sherpa & 7502 & 35.21 & 7.27 & 2641 \\
\hline Central & e.Sindhupalchok & Ghale & 651 & 35.70 & 7.56 & 232 \\
\hline Central & e.Sindhupalchok & Gharti/Bhujel & 2641 & 38.11 & 7.51 & 1006 \\
\hline Central & e.Sindhupalchok & Magar & 4896 & 40.98 & 7.68 & 2007 \\
\hline Central & e.Sindhupalchok & Kami & 11241 & 41.53 & 7.50 & 4668 \\
\hline Central & e.Sindhupalchok & Tamang & 99181 & 42.04 & 7.42 & 41699 \\
\hline Central & e.Sindhupalchok & Damai/Dholi & 5483 & 42.49 & 7.52 & 2330 \\
\hline Central & e.Sindhupalchok & Sarki & 4411 & 42.85 & 7.51 & 1890 \\
\hline Central & e.Sindhupalchok & Danuwar & 3651 & 45.49 & 7.29 & 1661 \\
\hline Central & e.Sindhupalchok & Thami & 4907 & 45.93 & 7.90 & 2254 \\
\hline Central & e.Sindhupalchok & Majhi & 6613 & 47.94 & 7.65 & 3170 \\
\hline Central & e.Sindhupalchok & Pahari & 1899 & 49.32 & 7.54 & 937 \\
\hline Central & f.Rasuwa & Brahman - Hill & 6458 & 11.42 & 3.78 & 738 \\
\hline Central & f.Rasuwa & Chhetree & 851 & 12.78 & 3.87 & 109 \\
\hline Central & f.Rasuwa & Newar & 982 & 26.93 & 6.85 & 264 \\
\hline Central & f.Rasuwa & Gurung & 1327 & 33.63 & 7.96 & 446 \\
\hline Central & f.Rasuwa & Magar & 510 & 34.89 & 8.49 & 178 \\
\hline Central & f.Rasuwa & Ghale & 1023 & 37.86 & 7.23 & 387 \\
\hline Central & f.Rasuwa & Damai/Dholi & 441 & 38.81 & 7.78 & 171 \\
\hline Central & f.Rasuwa & Tamang & 29600 & 39.63 & 7.41 & 11730 \\
\hline Central & f.Rasuwa & Kami & 802 & 40.44 & 7.45 & 324 \\
\hline Western & g.Manang & Gurung & 3362 & 29.79 & 8.02 & 1001 \\
\hline Western & g.Manang & Ghale & 438 & 32.56 & 7.97 & 143 \\
\hline Western & g.Manang & Kami & 217 & 36.11 & 8.19 & 78 \\
\hline Western & g.Manang & Bhote & 409 & 43.53 & 7.82 & 178 \\
\hline Western & g.Manang & Tamang & 732 & 48.77 & 8.23 & 357 \\
\hline Western & h.Mustang & Brahman - Hill & 344 & 4.49 & 3.09 & 15 \\
\hline Western & h.Mustang & Chhetree & 727 & 14.55 & 4.42 & 106 \\
\hline Western & h.Mustang & Thakali & 2699 & 21.89 & 6.75 & 591 \\
\hline Western & h.Mustang & Gurung & 2314 & 24.20 & 6.52 & 560 \\
\hline Western & h.Mustang & Lhopa & 2259 & 26.95 & 6.28 & 609 \\
\hline Western & h.Mustang & Magar & 875 & 34.07 & 7.77 & 298 \\
\hline Western & h.Mustang & Damai/Dholi & 511 & 34.19 & 6.77 & 175 \\
\hline Western & h.Mustang & Kami & 1022 & 36.70 & 7.62 & 375 \\
\hline Mid-western & i.Dolpa & Brahman - Hill & 575 & 12.55 & 5.65 & 72 \\
\hline Mid-western & i.Dolpa & Thakuri & 2354 & 23.22 & 5.86 & 547 \\
\hline Mid-western & i.Dolpa & Chhetree & 16437 & 26.86 & 5.87 & 4415 \\
\hline Mid-western & i.Dolpa & Tamang & 425 & 44.37 & 7.71 & 188 \\
\hline Mid-western & i.Dolpa & Magar & 4561 & 45.91 & 7.39 & 2094 \\
\hline Mid-western & i.Dolpa & Gurung & 2592 & 49.38 & 7.59 & 1280 \\
\hline Mid-western & i.Dolpa & Dolpo & 4095 & 54.79 & 7.83 & 2244 \\
\hline Mid-western & i.Dolpa & Kami & 3342 & 57.17 & 7.66 & 1911 \\
\hline Mid-western & i.Dolpa & Sarki & 1011 & 59.68 & 7.60 & 604 \\
\hline Mid-western & i.Dolpa & Damai/Dholi & 571 & 61.42 & 6.96 & 351 \\
\hline Mid-western & j.Jumla & Brahman - Hill & 11889 & 19.91 & 5.17 & 2367 \\
\hline Mid-western & j.Jumla & Sanyasi/Dashnami & 1218 & 28.62 & 6.12 & 349 \\
\hline Mid-western & j.Jumla & Thakuri & 7978 & 30.85 & 6.19 & 2461 \\
\hline Mid-western & j.Jumla & Chhetree & 65536 & 32.56 & 6.05 & 21336 \\
\hline Mid-western & j.Jumla & Lohar & 1011 & 39.83 & 6.44 & 403 \\
\hline Mid-western & j.Jumla & Tamang & 1216 & 45.45 & 7.62 & 553 \\
\hline Mid-western & j.Jumla & Sarki & 7732 & 53.42 & 7.50 & 4131 \\
\hline Mid-western & j.Jumla & Kami & 7989 & 57.78 & 7.58 & 4616 \\
\hline
\end{tabular}

Social Inquiry: Journal of Social Science Research, Volume 2, Issue 2, 2020 


\begin{tabular}{|c|c|c|c|c|c|c|}
\hline Region & District & $\begin{array}{l}\text { Province/ } \\
\text { Caste_ethnicity }\end{array}$ & $\begin{array}{r}\text { Estimated } \\
\text { total } \\
\text { population }\end{array}$ & $\begin{array}{l}\text { Estimated } \\
\text { poverty rates } \\
(\%)\end{array}$ & $\begin{array}{l}\text { Standard } \\
\text { error of } \\
\text { poverty } \\
\text { rates }\end{array}$ & $\begin{array}{l}\text { Estimated } \\
\text { population below } \\
\text { poverty line }\end{array}$ \\
\hline Mid-western & j.Jumla & Damai/Dholi & 2768 & 57.88 & 7.53 & 1602 \\
\hline Mid-western & k.Kalikot & Sanyasi/Dashnami & 1364 & 29.87 & 6.14 & 407 \\
\hline Mid-western & k.Kalikot & Brahman - Hill & 23620 & 35.44 & 6.55 & 8371 \\
\hline Mid-western & k. Kalikot & Thakuri & 34672 & 38.02 & 6.47 & 13181 \\
\hline Mid-western & k.Kalikot & Chhetree & 39714 & 40.33 & 6.52 & 16016 \\
\hline Mid-western & k.Kalikot & Lohar & 722 & 42.69 & 6.97 & 308 \\
\hline Mid-western & k.Kalikot & Kumal & 753 & 61.62 & 7.67 & 464 \\
\hline Mid-western & k.Kalikot & Magar & 506 & 62.78 & 7.75 & 317 \\
\hline Mid-western & k.Kalikot & Sarki & 4475 & 66.24 & 7.03 & 2964 \\
\hline Mid-western & k.Kalikot & Kami & 24411 & 67.07 & 7.06 & 16373 \\
\hline Mid-western & k.Kalikot & Damai/Dholi & 7001 & 68.84 & 6.90 & 4819 \\
\hline Mid-western & 1.Mugu & Thakuri & 8524 & 29.76 & 6.12 & 2537 \\
\hline Mid-western & 1.Mugu & Brahman - Hill & 2852 & 31.28 & 5.63 & 892 \\
\hline Mid-western & 1.Mugu & Chhetree & 27057 & 32.88 & 6.02 & 8895 \\
\hline Mid-western & 1.Mugu & Sanyasi/Dashnami & 701 & 33.86 & 5.63 & 237 \\
\hline Mid-western & 1.Mugu & Tamang & 4383 & 54.84 & 7.57 & 2403 \\
\hline Mid-western & 1.Mugu & Damai/Dholi & 1768 & 57.36 & 7.85 & 1014 \\
\hline Mid-western & 1.Mugu & Dalit Others & 3258 & 60.25 & 7.30 & 1963 \\
\hline Mid-western & 1.Mugu & Kami & 5268 & 61.97 & 7.51 & 3265 \\
\hline Mid-western & 1.Mugu & Sarki & 473 & 62.63 & 7.40 & 296 \\
\hline Mid-western & 1.Mugu & Bhote & 348 & 69.83 & 7.06 & 243 \\
\hline Mid-western & m.Humla & Brahman - Hill & 3235 & 29.36 & 5.52 & 950 \\
\hline Mid-western & m.Humla & Chhetree & 19608 & 32.08 & 5.68 & 6291 \\
\hline Mid-western & m.Humla & Thakuri & 9995 & 32.46 & 5.92 & 3244 \\
\hline Mid-western & m.Humla & Tamang & 6569 & 40.21 & 7.55 & 2641 \\
\hline Mid-western & m.Humla & Byasi/Sanka & 2479 & 55.50 & 7.55 & 1375 \\
\hline Mid-western & m.Humla & Damai/Dholi & 1787 & 61.50 & 7.00 & 1099 \\
\hline Mid-western & m.Humla & Sarki & 1140 & 63.69 & 7.29 & 726 \\
\hline Mid-western & m.Humla & Kami & 4950 & 64.01 & 7.16 & 3168 \\
\hline Far-western & n.Bajura & Brahman - Hill & 9432 & 56.46 & 8.42 & 5325 \\
\hline Far-western & n.Bajura & Thakuri & 7026 & 58.44 & 8.06 & 4106 \\
\hline Far-western & n.Bajura & Sanyasi/Dashnami & 3252 & 59.99 & 8.22 & 1951 \\
\hline Far-western & n.Bajura & Chhetree & 78292 & 64.42 & 7.69 & 50437 \\
\hline Far-western & n.Bajura & Lohar & 5219 & 67.16 & 7.68 & 3506 \\
\hline Far-western & n.Bajura & Bhote & 1397 & 82.71 & 5.95 & 1155 \\
\hline Far-western & n.Bajura & Kami & 13202 & 85.23 & 5.27 & 11252 \\
\hline Far-western & n.Bajura & Sarki & 6772 & 85.30 & 5.32 & 5776 \\
\hline Far-western & n.Bajura & Damai/Dholi & 5744 & 86.12 & 5.12 & 4947 \\
\hline Far-western & n.Bajura & Badi & 1896 & 86.58 & 5.12 & 1642 \\
\hline Far-western & n.Bajura & Kumal & 441 & 86.97 & 4.79 & 384 \\
\hline Far-western & n.Bajura & Dalit Others & 1233 & 88.23 & 4.57 & 1088 \\
\hline Far-western & o.Bajhang & Thakuri & 9552 & 56.75 & 8.51 & 5420 \\
\hline Far-western & o.Bajhang & Brahman - Hill & 20002 & 59.41 & 8.36 & 11884 \\
\hline Far-western & o.Bajhang & Sanyasi/Dashnami & 2447 & 61.64 & 7.91 & 1508 \\
\hline Far-western & o.Bajhang & Chhetree & 130815 & 67.43 & 7.50 & 88215 \\
\hline Far-western & o.Bajhang & Sarki & 4363 & 84.29 & 5.57 & 3677 \\
\hline Far-western & o.Bajhang & Damai/Dholi & 3029 & 87.33 & 4.81 & 2645 \\
\hline Far-western & o.Bajhang & Dalit Others & 10020 & 87.44 & 4.67 & 8762 \\
\hline Far-western & o.Bajhang & Kami & 14438 & 87.58 & 4.69 & 12645 \\
\hline Far-western & p.Darchula & Thakuri & 6515 & 51.10 & 8.65 & 3329 \\
\hline Far-western & p.Darchula & Sanyasi/Dashnami & 1677 & 52.34 & 9.03 & 878 \\
\hline Far-western & p.Darchula & Brahman - Hill & 22379 & 52.53 & 8.70 & 11756 \\
\hline Far-western & p.Darchula & Chhetree & 86377 & 59.17 & 8.28 & 51106 \\
\hline Far-western & p.Darchula & Byasi/Sanka & 965 & 61.15 & 9.17 & 590 \\
\hline
\end{tabular}




\begin{tabular}{|c|c|c|c|c|c|c|}
\hline Region & District & $\begin{array}{l}\text { Province/ } \\
\text { Caste_ethnicity }\end{array}$ & $\begin{array}{r}\text { Estimated } \\
\text { total } \\
\text { population }\end{array}$ & $\begin{array}{l}\text { Estimated } \\
\text { poverty rates } \\
(\%)\end{array}$ & $\begin{array}{l}\text { Standard } \\
\text { error of } \\
\text { poverty } \\
\text { rates }\end{array}$ & $\begin{array}{l}\text { Estimated } \\
\text { population below } \\
\text { poverty line }\end{array}$ \\
\hline Far-western & p.Darchula & Lohar & 1727 & 70.63 & 7.23 & 1220 \\
\hline Far-western & p.Darchula & Dalit Others & 4199 & 83.42 & 5.65 & 3503 \\
\hline Far-western & p.Darchula & Damai/Dholi & 974 & 83.49 & 5.81 & 813 \\
\hline Far-western & p.Darchula & Kami & 7078 & 86.20 & 5.03 & 6102 \\
\hline Far-western & p.Darchula & Sarki & 902 & 88.10 & 4.57 & 795 \\
\hline Total & & & & & & 718,033 \\
\hline
\end{tabular}

Note: aggregate of caste/ethnicities within each district does not match to district total because of exclusion of small caste/ethnic groups.

\section{Author Biosketch}

Bhim Raj Suwal, PhD, is an Associate Professor at the Central Department of Population Studies, Tribhuvan University, Kathmandu. Dr. Suwal specializes in demographic techniques, human migration, scientific sample design and estimation, planning and execution of large-scale surveys, and quantitative data analysis. He has received a two-month intensive training on scientific sample design from the University of Michigan, USA and working as sampling expert and statistician in various research projects supported by the Government of Nepal and development partners. He has published a number research articles in national and international journals. $\mathrm{He}$ also served as Assistant Dean (PhD Coordinator) and Acting Dean under the Faculty of Humanities and Social Sciences, Tribhuvan University.

To cite this article: Suwal, B. R. (2020). Spatial variation of caste/ethnic poverty in mountain districts of Nepal: An approximation through small area estimation technique. Social Inquiry: Journal of Social Science Research, 2(2), 158193. https://doi.org/10.3126/sijssr.v2i2.33059

\section{For other articles and journal archive, visit:}

1. http://socialinquiryjournal.org/index.php

2. https://www.nepjol.info/index.php/sijssr/index 